\title{
THE EFFECTIVENESS OF COLEUS AMBOINICUS LEAF EXTRACTS AS AN ANALGETIC ACTIVITY ON MICE EXPOSURED TO ACETIC ACID
}

\section{YUNITA SARI PANE ${ }^{1 *}$, SUFITNI SUFITNI ${ }^{2}$, FITRIANI LUMONGGA ${ }^{2}$, NURFIDA ALRASYID ${ }^{3}$, DINI PERMATA SARI ${ }^{4}$, RIDHA WATI ${ }^{5}$, MOHAMMAD BASYUNI ${ }^{5 *}$}

${ }^{1}$ Department of Pharmacology \& Therapeutic, Universitas Sumatera Utara, Medan, North Sumatera, Indonesia. ${ }^{2}$ Department of Anatomy, Universitas Sumatera Utara, Medan, North Sumatera, Indonesia. ${ }^{3}$ Department of Parasitology, Universitas Sumatera Utara, Medan, North Sumatera, Indonesia. ${ }^{4}$ Department of Pharmacology, Faculty of Pharmacy, Universitas Sumatera Utara, Medan 20155, Indonesia. ${ }^{5}$ Department of Forestry, Faculty of Forestry, Universitas Sumatera Utara, Jl. Tri Dharma Ujung No. 1 Medan, North Sumatra, 20155, Indonesia. E-mail: yunitasaripane@yahoo.com/m.basyuni@usu.ac.id

Received: 09 April 2018, Revised and Accepted: 29 May 2018

ABSTRACT

Objective: This study aims to observe the analgesic activity of Bangun-bangun (Coleus amboinicus) leaves by induction of pain arising from chemical excitement after exposure to acetic acid.

Methods: The effectiveness test of water extract and ethanol extract of Bangun-bangun leaves as an analgesic was measured by comparing the mean of quantitative and the writhing between control and treatment group. In addition, observations on the decrease in inflammatory processes occurred by calculating the reduction in the number of leukocyte migration to the inflammatory area.

Result: The decrease of excitatory pain in all treatment Groups (I-IV) were significantly different. The comparison of mean values \pm SEM decreased excitatory pain Groups I-II (255.00 $\pm 22.22 ; 88.33 \pm 14.58)$, $p=0.000$. Groups I-III $(255.00 \pm 22.22 ; 60.00 \pm 10.04)$, $p=0.000$ and Groups I-IV (255.00 \pm 22.22 ; $50.83 \pm 3.09)$, $p=0.000$. On histopathology examination, all treatment groups were significantly different $(p=0.006)$. The comparison of mean value \pm SEM decrease number of leukocyte Groups I-II (31.73 $\pm 5.22 ; 14.70 \pm 3.71)$, p=0.025. Groups I-III $(31.73 \pm 5.22 ; 15.67 \pm 3.22)$, p=0.036 and Groups I-IV $(31.73 \pm 5.22 ; 11.77 \pm 2.77), p=0.008$. However, the comparison of decrease of excitatory of pain and number of leukocyte migration between each group did not show significantly different $(\mathrm{p}>0.05)$.

Conclusions: This study concluded that the Bangun-bangun leaves both in the form of water extract and ethanol extract proved efficacious as a pain reliever in the mice after induction of acetic acid.

Keywords: Bangun-bangun leaves (Coleus amboinicus), Analgetic, Ethanol extract, Leukocytes, Writhing response, Leukocyte migration.

(C) 2018 The Authors. Published by Innovare Academic Sciences Pvt Ltd. This is an open access article under the CC BY license (http://creativecommons. org/licenses/by/4. 0/) DOI: http://dx.doi.org/10.22159/ajpcr.2018.v11i9.26538

\section{INTRODUCTION}

Pain is a mechanism to protect the body against a disorder and tissue damage such as inflammation, microorganism infection, and muscle spasms with the release of pain mediators including prostaglandins (PG), bradykinin, serotonin, histamine, potassium ions, and acetylcholine [1]. Pain is a symptom that patients often complain to clinical practitioners in hospitals and practices. Pain complaints cause the use of pure/synthetic chemical analgesic drugs to increase which can lead to many unwanted side effects even fatal such as death. Pain also serves as a defense that allows for the immobilization of organs that are inflamed or broken so that the perceived sensible will subside and can accelerate the healing, pain also serves as a diagnostic guide, because with the pain in specific areas, the process that occurs in patients can be known [2]. Currently, the development of traditional herbal medicine, especially in Indonesia is very rapid because it is supported by the government. Use of medicinal plants is considered active and does not cause harmful side effects, mainly when consumed in the long term. But without scientific studies, herbal medicine cannot be used for formal health services (modern) although empirically has proven usefulness. The trend in the community reuse natural treatment (back to nature), such as Bangun-bangun leaves (Coleus amboinicus) and others. The Bangun-Bangun leaves are known to be efficacious as breast milk enhancers, antimicrobial, anti-inflammatory and antioxidants as reported in phytochemical databases [3]. The Bangun-bangun leaves contain $0.2 \%$ essential oil, including carvacrol and isopropyl-o-cresol, phenol, sineol and potassium $6.4 \%$. The extract of Bangun-bangun which is distilled by a high vapor is known to contain volatile oil of $0.5 \%$ with a hexane compound of $6.5 \%$. Until now that has been identified about 30 chemical components contained in essential oils and carvacrol (50-90\%) is the primary compound. Phytochemical database reported that in this leaf there is also the content of Vitamin C, Vitamin B1, Vitamin B12, beta-carotene, niacin, carvacrol, calcium, fatty acids, oxalic acid, and fiber [3].

From study literature, we have never encountered a study reporting on the effect of Bangun-bangun leaves in reducing excitatory pain associated with the activation of leukocyte in mice [4]. This study aims to observe the analgesic activity of Bangun-bangun leaves by induction of pain arising from chemical excitement after exposure to acetic acid as one of the factors that can cause inflammation. This study used paracetamol as a positive control that works by inhibiting PG synthesis in the hypothalamus. Paracetamol is known as an antipyretic analgesic $[5,6]$.

This study is expected to complete information about the efficacy of Bangun-bangun leaves and as evidence has been done pre-clinical scientific studies use of Bangun-bangun leaves as an analgesic to pain due to inflammation. This research is expected to be continued to the level of clinical research so that later can be used as alternative medicine from synthetic pain remedy that circulated during this time. Therefore the present study aimed to determine the analgesic activity of Bangun-bangun leaves by induction of pain arising from chemical excitement after exposure to acetic acid. 


\section{METHODS}

\section{Preparation of water extract Bangun-Bangun leaves}

The Bangun-Bangun leaves were obtained from Tanah Karo Brastagi Medan, North Sumatra, Indonesia and some traditional markets in Medan. Identification of Bangun-bangun leaves was conducted at Herbarium Medanense, Medan, North Sumatra. A specimen voucher has been deposited there.

The Bangun-bangun leaves are made into water extracts according to use in instruction in Indonesian Pharmacopoeia (1972) [7]. Leaves were washed first and then aerated for one night. The fresh leaves are weighed, and then thinly sliced, distilled water added 1:1 subsequently heated at $90^{\circ} \mathrm{C}$ for $30 \mathrm{~min}$, after cold filtered with filter paper, and then measured the volume obtained. The dosage of the water extract for the mice was determined by the dose of Santosa's study in decreased and increase a half initial treatment [7].

\section{Preparation of ethanol extract Bangun-bangun leaves (EDBB)}

The preparation of EEDB is done according to the technique of making ethanol extract by Laboratory of Pharmacy's procedures in Universitas Sumatera Utara. The dose used in this study was $144 \mathrm{mg} / 20 \mathrm{~g}$ BB mice in $36 \%$ concentration. For EEDB administration, the pure extract was dissolved with $1 \% \mathrm{CMC}$

\section{Selection of acetic acid dose}

It was determined that the dosage should be applied at a concentration of $1 \%$, in which the solution was prepared by diluting glacial acetic acid, then the solution was tested at three dose levels as follows: $25 \mathrm{mg} / \mathrm{kg} \mathrm{BW}, 50 \mathrm{mg} / \mathrm{kg} \mathrm{BW}$, and $75 \mathrm{mg} / \mathrm{kg} \mathrm{BW}$. It aims to find doses that cause the amount of writing is not too much and a little, making it easier to observe. The right dose of $1 \%$ acetic acid injection found as much as $0.3 \mathrm{cc}$ as in the study [8].

\section{Determination of doses of paracetamol}

In $1 \%$ paracetamol, the suspension was prepared by weighing $100 \mathrm{mg}$ of paracetamol then crushed and added CMC Na $1 \%$ bit by bit so that the volume was $10 \mathrm{~mL}$ [9].

The dose of paracetamol $=10 \mathrm{~mL}=100 \mathrm{mg}$ of paracetamol

$=1 \mathrm{~mL} / \times=10 \mathrm{mg} / 2 \mathrm{mg}$

$\mathrm{x}=0.2 \mathrm{cc}$

Efficacy of Bangun-bangun leaves extracts as an analgesic A total of 24 mice (Mus musculus) aged 10-12 weeks with an average weight of $20 \mathrm{~g}$ were adapted for 2 weeks. The study has been approved by Animal Research Ethics Committees (AREC) of Universitas Sumatera Utara, and the experiments were conducted according to the ethical norms and AREC guidelines.

Mice are divided into four groups consisting of six each group. Group-I as a negative control/placebo was given Aquadest of $0.2 \mathrm{cc} / 20 \mathrm{~g}$ BB mice. Group-II was given as a positive control given paracetamol $2 \mathrm{mg} / 20 \mathrm{~g}$
BB mice. Group-III was given of water extract Bangun-bangun leaves (DBB) $0.5 \mathrm{~g} / 20 \mathrm{~g}$ BB mice, and Group IV was given of EDBB leaves $144 \mathrm{mg} / 20 \mathrm{~g}$ BB mice. All treatments were given orally $10 \mathrm{~min}$ before intraperitoneal injection of acetic acid was induced. Direct observation performed for $1 \mathrm{~h}$ (from 0 to $60 \mathrm{~min}$ after injection). To prevent the observation subjectivity bias, observations were made by recording video from all treatment groups to cross-check the observations. At $4 \mathrm{~h}$ after exposure, an execution was performed by performing a cervical fracture in the mice to retrieve the peritoneal tissue in the induced area of acetic acid injection. The peritoneal tissue is made into histopathologic preparations. Observations were made of the number of leukocyte migrations to the inflammatory area using Olympus light microscope devices with $\times 400$ magnification.

\section{Determination of criteria writhing}

The determining of the writhing criterion by pulling one or both legs backward.

\section{Determination of the count of leukocyte}

Leukocyte migration located in the inflammatory area of the peritoneal tissue. Counting the number of leukocytes calculated in each field of large view $(\times 400)$, to be more objective, leukocyte count $\times 5$ as much, per field of large view in a different area. The result is average of leukocytes each large view.

\section{Data analysis}

The significant difference of data between different groups was compared by ANOVA followed by Tukey test.

\section{RESULTS AND DISCUSSION}

The effect of observation on the number of stretching responses is obtained by counting each minute writhing quantity for one h, displayed in Table 1 .

From the ANOVA analysis test, there was a statistically significant difference in all treatment groups $(\mathrm{p}=0.000)$. Then, we performed a follow-up test (post hoc Tukey) to see the differences between treatment groups.

The observation of the number of leukocyte migrations to the inflammatory area by counting each leukocyte in $\times 5$ viewpoint under the Olympus light microscope with $\times 400$ magnification as depicted in Table 2 .

From the ANOVA analysis test, there was a statistically significant difference in all treatment groups $(\mathrm{p}=0.000)$. Then, performed a followup test (post hoc Tukey) to see the differences between treatment groups.

The histopathologic feature of leukocyte migration to the inflammatory area of intraperitoneal tissue as depicted in the following Fig. 1.

\section{DISCUSSION}

The amount of decrease in the writhing response was the most prevalent in the IV-EDBB group $(50.83 \pm 3.09)$, significantly

Table 1: The response of writhing

\begin{tabular}{|c|c|c|c|c|}
\hline \multirow[t]{2}{*}{ No } & \multicolumn{4}{|c|}{ The response of writhing per minute in $1 \mathrm{~h}$} \\
\hline & $\begin{array}{l}\text { Group-I negative } \\
\text { control/placebo }\end{array}$ & $\begin{array}{l}\text { Group-II positive } \\
\text { control paracetamol }\end{array}$ & $\begin{array}{l}\text { Group-III DBB } \\
0.5 \mathrm{~g} / 20 \mathrm{~g} \text { mice }\end{array}$ & $\begin{array}{l}\text { Group-IV EDBB } \\
144 \mathrm{mg} / 20 \mathrm{~g} \text { mice }\end{array}$ \\
\hline 1 & 186 & 80 & 113 & 43 \\
\hline 2 & 215 & 124 & 83 & 55 \\
\hline 3 & 332 & 36 & 91 & 60 \\
\hline 4 & 267 & 78 & 69 & 41 \\
\hline 5 & 232 & 78 & 122 & 50 \\
\hline 6 & 298 & 134 & 75 & 56 \\
\hline Total & 1530 & 530 & 305 & 112 \\
\hline Mean \pm SEM & $255.00 \pm 22.22$ & $88.33 \pm 14.58$ & $60.00 \pm 10.04$ & $50.83 \pm 3.09$ \\
\hline
\end{tabular}


Table 2: Leukocyte migration

\begin{tabular}{|c|c|c|c|c|}
\hline \multirow[t]{2}{*}{ No } & \multicolumn{4}{|c|}{ The number of leukocyte migration to inflammation area } \\
\hline & $\begin{array}{l}\text { Group-I negative } \\
\text { control/placebo }\end{array}$ & $\begin{array}{l}\text { Group-II positive } \\
\text { control paracetamol } 0.2 \mathrm{cc}\end{array}$ & $\begin{array}{l}\text { Group-III DBB } \\
0.5 \mathrm{~g} / 20 \mathrm{~g} \text { mice }\end{array}$ & $\begin{array}{l}\text { Group-IV EDBB } \\
144 \mathrm{mg} / 20 \mathrm{~g} \text { mice }\end{array}$ \\
\hline 1 & 23 & 24 & 22.8 & 5.6 \\
\hline 2 & 21.2 & 12.6 & 17.6 & 24.6 \\
\hline 3 & 21.4 & 8.4 & 5.6 & 11.6 \\
\hline 4 & 52.8 & 28 & 16.4 & 8.4 \\
\hline 5 & 40.6 & 9 & 24.6 & 12.6 \\
\hline 6 & 31.4 & 6.2 & 7 & 7.8 \\
\hline Total & 190 & 88.2 & 94 & 70.6 \\
\hline Mean \pm SEM & $31.73 \pm 5.22$ & $14.70 \pm 3.71$ & $15.67 \pm 3.22$ & $11.77 \pm 2.77$ \\
\hline
\end{tabular}

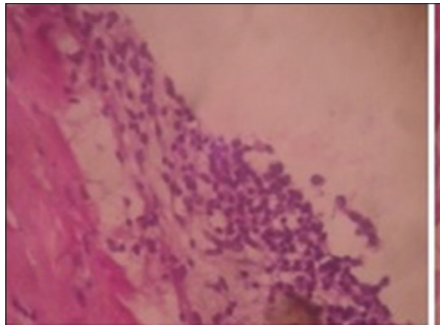

Group-I

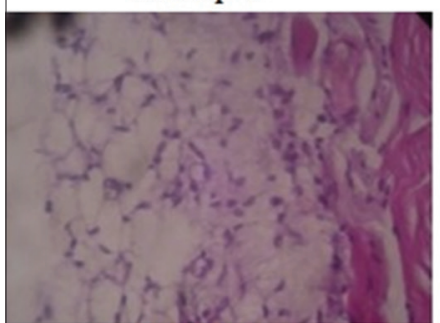

Group-III

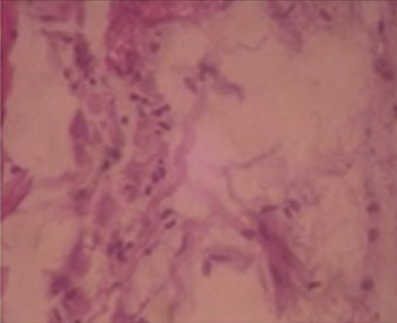

Group-II

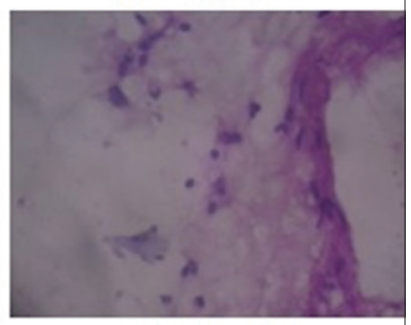

Group-IV
Fig. 1: The histopathologic feature of leukocyte migration to the inflammatory area of intraperitoneal tissue

different when compared with the negative control/placebo group $(255.00 \pm 22.22 ; \mathrm{p}=0.000)$. In contrary, when compared between the Group-IV (EDBB) $(50.83 \pm 3.09)$ with the Group-II control positive/ paracetamol $(88.33 \pm 14.58)$ and the Group-III DBB $(60.00 \pm 10.04)$, not significantly different ( $p>0.05$ ). It is believed that the Bangun-bangun leaves have carvacrol as an anti-inflammatory and antioxidant agent. Carvacrol is a phenolic monoterpene present in the essential oil of Bangun-bangun leaves. Guimarães et al. suggested that carvacrol is useful as an analgesic compound in various nociceptive models, probably by inhibition of peripheral mediators that could be related to its potent antioxidant effect observed in vitro. In their study, the antihypernociceptive activity of carvacrol was tested in mice through models of mechanical hypernociception induced by carrageenan, and the involvement of significant mediators of its signaling cascade, such as tumor necrosis factor-alpha, PGE(2), and dopamine, were assessed [10]. Those studies add information about the beneficial effects of carvacrol on mechanical hypernociception and inflammation. It also indicates that this monoterpene might be potentially engaging in the development of novel tools for management and treatment of painful conditions, including those related to inflammatory, prooxidant states, and other external attacks [11]. The study of Lima et al. in 2012 states that the effects of carvacrol cause anti-inflammatory effects by reducing the production of inflammatory mediators, such as IL-1 $\beta$ and prostanoid, possibly through induction of IL-10 release [12].

The number of decrease in the leukocyte migration was the most prevalent in the Group-I VEDBB $(11.77 \pm 2.77)$, significantly different when compared with the Group-II negative control/placebo $(31.73 \pm 5.22 ; \mathrm{p}=0.000)$. In contrary, when compared between the
IV-EDBB group $(11.77 \pm 2.77)$ with the Group-II positive control/ paracetamol $(14.70 \pm 3.71)$ and the Group-III DBB $(15.67 \pm 3.22)$, did not significantly different ( $>0.05$ ) (Table 2). The Bangun-bangun leaves that consist of carvacrol can decrease leukocyte migration to inflammation area. This circumstance is appropriate to study of Fachini-Queiroz et al. that research about the anti-inflammatory effects of TEO and CVL are attributable to the inhibition of inflammatory edema and leukocyte migration [13]. The Bangun-bangun leaves have been reported to contain flavonoids [14]. The previous studies have shown similar relationships between flavonoids and anti-inflammatory effects [15-17]. Therefore, it is possible that the anti-inflammatory action of Bangun-bangun leaves extracts may be related to the inhibition of PG synthesis.

\section{CONCLUSION}

Our study demonstrated that the Bangun-bangun leaves both in the form of water extract and ethanol extract proved efficacious as a pain reliever in the mice after induction of acetic acid. Even the Group-IV (EDBB) has the best efficacy as analgesic compares to the Group-II (positive control/paracetamol) and Group-III (DBB) in decreasing the writhing response and migration of leukocyte to the inflamed tissue.

\section{ACKNOWLEDGMENT}

The authors are grateful to Lembaga Penelitian Universitas Sumatera Utara which has provided funding support through research project number: 5338/UN5.1R/PPM/2017.

\section{AUTHORS' CONTRIBUTION}

YSP designed and performed the experiments. YSP and FL derived the models and analyzed the data. YSP, DPS, and RW wrote the manuscript in consultation with MB, S, NA. All of the authors read and approved the final manuscript.

\section{CONFLICTS OF INTEREST}

The authors declare that they have no competing interests.

\section{REFERENCES}

1. Jacob L, Kostev K. Prevalence of pain medication prescriptions in France, Germany, and the UK-a cross-sectional study including 4,270,142 patients. J Postgrad Med 2018;130:32-6

2. Sutrisno E, Adnyana K, Sukandar EY, Fidrianny I, Aligita W. Antiinflammatory study of Anredera cordifolia leaves and Centella asiatica herbs and its combination using human red blood cell-membrane stabilization method. Asian J Pharm Clin Res 2016;9:78-80.

3. Mills S, Bone K. Principle and Practice of Phytotherapy Modern Herbal Medicine. Seattle: Churchill of Washington; 2000.

4. Santosa CM, Hertiani T. Chemical compound and wilted leaves extract effect (Coleus amboinicus L.) on neutrophil rodent phagocytic activity of white rat (Rattus norvrgicus). Pharm Mag Indones 2005;16:141-8.

5. Gunawan A. Comparison of analgesic effect between paracetamol with combination of paracetamol and caffeine in mice. J Biomed 2009;1:37-43. 
6. Katzung BG, Trevor AJ. Basic and Clinical Pharmacology. $12^{\text {th }}$ ed. San Francisco: McGraw Hill Education Lange; 2015.

7. Silitonga M. Lactagogum Effect of Cumin Leaves (Coleus amboinicus, L.) in Lactation Mice. Master's Thesis of Science, Biology Study Program. Bogor: Bogor Agricultural University; 1993.

8. Tatiya AU, Saluja AK, Kalaskar MG, Surana SJ, Patil PH. Evaluation of analgesic and anti-inflammatory activity of Bridelia retusa (Spreng) bark. J Tradit Complement Med 2017;7:441-51.

9. Widhianata AH. Efek Analgesik Jus Umbi Wortel (Daucus Carota L) Pada Mencit Putih Betina, Skripsi. Yogyakarta: Program Studi Ilmu Farmasi Fakultas Farmasi Universitas Sanata Dharma; 2007.

10. Guimarães AG, Xavier MA, Santana MT, Camargo EA, Santos CA, Brito FA, et al. Carvacrol attenuates mechanical hypernociception and inflammatory response. Naunyn Schimiedeberg's Arch Pharmacol 2012;385:253-63.

11. Basyuni M, Kinjo Y, Baba S, Shinzato N, Iwasaki H, Siregar EB, et al. Isolation of salt tolerance genes from roots of mangrove plant, Rhizophora stylosa Griff., using PCR-based suppression subtractive hybridization. Plant Mol Biol Rep 2011;29:533-43.
12. Lima MD. Anti-inflammatory effects of carvacrol: Evidence for a key role of interleukin-10. Eur J Pharmacol 2013;699:112-7.

13. Fachini QF, Kummer R, Estevao SC. Effects of thymol and carvacrol, constituents of Thymus vulgaris L. essential oil, on the inflammatory response. Evid Based Complement Altern Med 2012;2012:1-10.

14. Robles JA, Yu GF. The anti-asthmatic effect of the combined yerba buena (Mentha arvensis Linn.) and oregano (Coleus amboinicus Lour.) leaves in BALB/c mice model of allergic asthma. Acta Med Philipp 2017;51:86.

15. Laaboudi W, Ghanam J, Aissam H, Merzouki M, Benlemlih M. Antiinflammatory and analgesic activities of olive tree extract. Int J Pharm Pharm Sci 2016;8:414-9.

16. Shaikh S, Joshi YM, Kadam V. Comparative study of anti-inflammatory activity if aqueous and methanolic extracts of Hibiscus cannabinus leaf (malvaceae). Int J Pharm Pharm Sci 2016;8:64-8.

17. Lincy MP, Mohan VR, Jeeva S. Anti-inflammatory activity of aerial part of Maerua apetala roth (Jacobs) against carrageenan induced paw edema. Int J Curr Pharm Res 2014;5:131-7. 